(America), and it is therefore perhaps more likely that it naturally feeds on some other species of Solanum in the inland regions of Africa, and has spread thence on a congenial food-plant being brought to meetit. It remains only to suggest an effectual remedy; this I am, unfortunately, unable to do. The larva being an internal feeder, no external washes or dressings could produce any effect, nor is it discoverable without digging up the plant. Should a crop be discovered, on harvesting, to be infested with this insect, the worthless tubers should not be thrown aside, but carefully destroyed with fire; this would go far to diminish the numbers of the insects next season, but although it might keep them in check, would not be effectual as a cure ; and the moth, whose appearance would soon be learnt, might also be destroyed when seen. As the insect is now established, no other precautions are available.

On two new species of Helix from the Louisiade Archipelago, By James C. Cox, M.D., F.L.S., \&c.,

\title{
Plate 16.
}

\section{1.-Heurx (Geotrochus) Gurgustir, Fig. 1.}

Shell imperforate, broadly conoid, white, diaphanous, opaque, shining, granular on the surface; whorls fine, gradually increasing in size, flat, last sharply angled at the periphery, pinched and everted at the peristome, reflexed at the insertion; base flat; peristome bright pink, lunulately-elongated, margins approached, everted and beaked at the centre; aperture white within.

Diameter, greatest 1.10 ; least 0.84 ; height 0.80 of an inch.

Habitat, Rossell Island, Louisiade Islands, Torres' Straits.

This fine species is in the Hargravesian Collection in the Australian Museum; it is the same type of shell as Hetix Louisiadensis of MacGillivray, but is a larger species, easily 
distinguished from that species by its white diaphanous aspect, light pink peristome, and by the absence of the characteristic oblique fine striæ on the surface of the whorls.

\section{2.-Helix (Geotrochus) Chapmani, Fig. 2.}

Shell imperforate, trochiform, very finely transversely striated from above downwards, and longitudinally striated with fine waved lines, white, diaphanous, shining; spire conical, whorls six, gradually increasing in size, apex acute, suture impressed, last whorl reflected, angulate at the periphery; base flattened; aperture oblique, irregularly ovately-lunate, margins approached joined by a dark reddish-black callus; peristome expanded and reflexed, margined externally with two narrow bands, the one next the lip orange-red, the other above but close to the last, dark black; these two coloured bands show through the shell and margin the internal edge of the peristome the same as they do the external edge; columella adnate, broad and expanded, coloured by the blending of the two coloured bands of a black and orange-red; interior of the aperture beyond the bands white.

Diameter, greatest $1 \cdot 14$; least 1.00 ; height 1.30 of an inch.

Habitat, Rossell Island, one of the Louisiade Group of Islands, Torres' Straits.

This lovely species is also in Mr. Hargrave's collection, recently purchased and presented to the Australian Museum by Mr. Thomas Walker, of Concord. The only shell having any pretention to the beauty of this fine species is Helix xanthocheila, Pfr. It is a more solid and opaque shell than xanthocheila, more broadly conoid, and the lip is less expanded. I have named it in honour of my friend Captain W. C. Chapman, R.N., late in command of H. M. Ship Dido, who laboured hard during his cruises through the Pacific Islands to develope their beautiful fauna. 
The other figure on Plate 16 represents Asplenium Prenticei, a new Fern from Queensland, descrbed by Mr. F. M. Bailey, F.L.S., in the proceedings of this Society last Month, ante page 36.

\section{EXHIBITS.}

Dr. Cox exhibited a splendid specimen of Turbinaria crater, attached to an unusually large Pearl Oyster shell; also the flow er of Haemanthus tigrinus, from the garden of Mr. Macdonald; and the two new Helices described in his paper.

Mr. Masters exhibited specimens collected on the Beach at Manly after a storm, of Glaucus, Porpita, Janthina, Physalia, (2 species), and Velella cyanea.

Mr. E. Meyrick exhibited the Potato-destroying Moth described by him.

Dr. R. B. Read laid before the Society some very interesting particulars in reference to the construction and maintainance of Aquaria. 


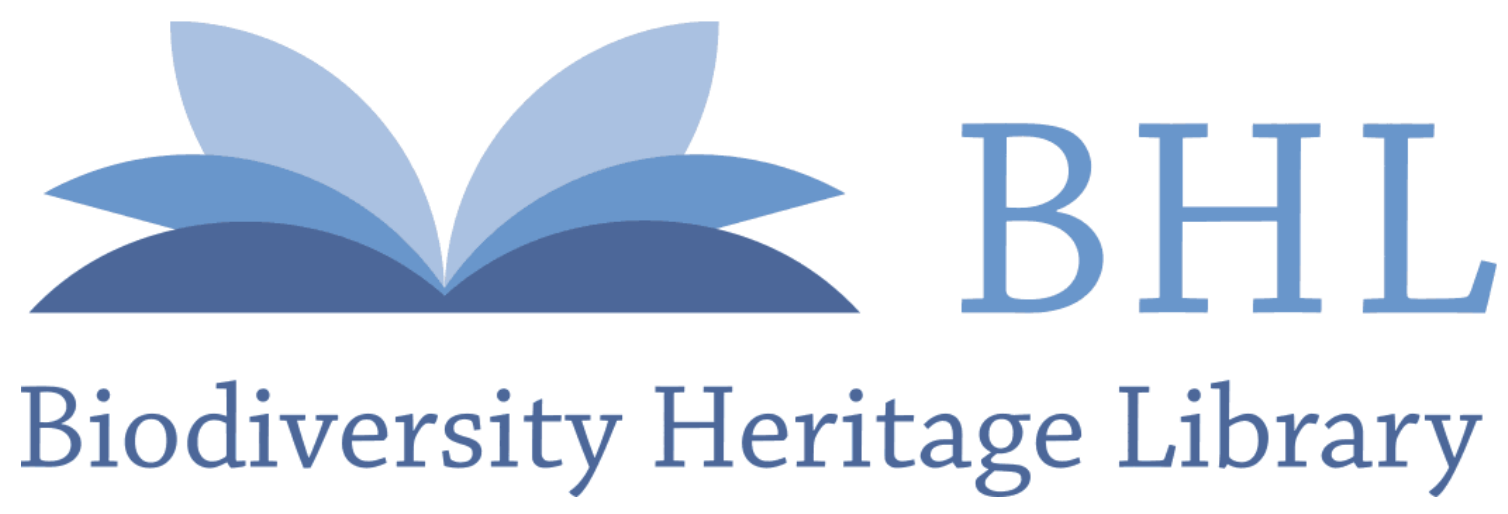

Cox, James Charles. 1879. "On two new species of Helix from the Louisiade Archipelago." Proceedings of the Linnean Society of New South Wales 4, 114-116. https://doi.org/10.5962/bhl.part.22844.

View This Item Online: https://www.biodiversitylibrary.org/item/30154

DOI: https://doi.org/10.5962/bhl.part.22844

Permalink: https://www.biodiversitylibrary.org/partpdf/22844

\section{Holding Institution}

MBLWHOI Library

Sponsored by

MBLWHOI Library

\section{Copyright \& Reuse}

Copyright Status: NOT_IN_COPYRIGHT

This document was created from content at the Biodiversity Heritage Library, the world's largest open access digital library for biodiversity literature and archives. Visit BHL at https://www.biodiversitylibrary.org. 